\title{
PIRACTWO MORSKIE I JEGO IMPLIKACJE DLA BEZPIECZEŃSTWA MORSKIEGO W DRUGIEJ DEKADZIE XXI WIEKU - CASUS SOMALII
}

\begin{abstract}
Zapewnienie bezpieczeństwa w XXI wieku jest istotne dla stabilnego rozwoju wszystkich państw na świecie. Nowe wyzwania i zagrożenia, które pojawiły się po atakach terrorystycznych z 11 września 2001 r. zmusiły społeczność międzynarodową do nowego spojrzenia na bezpieczeństwo oraz do zmiany strategicznego podejścia do problemów takich jak globalny terroryzm, przestępczość zorganizowana, proliferacja broni masowego rażenia, nielegalna imigracja czy piractwo morskie. W XXI wieku powyższe zagrożenia są określane mianem zagrożeń asymetrycznych, które w przeważającej większości są konsekwencją niewydolności państw oraz ich dysfunkcyjności. Fakt występowania państw słabych i dysfunkcyjnych, czyli takich które nie mogą wykonywać swoich podstawowych funkcji bezpieczeństwa i rozwoju oraz nie sprawują skutecznej kontroli nad swoimi terytoriami (lądowymi i morskimi), powoduje, że stają się one bezpośrednim źródłem zagrożeń asymetrycznych i są one łatwym obszarem do przejęcia przez organizację terrorystyczną czy przestępczą. Państwa indywidualnie mogą mieć problemy z zapewnieniem bezpieczeństwa, gdyż zwalczanie zagrożeń asymetrycznych wymaga stałej kooperacji wielu podmiotów i jest kosztowne, aby skuteczność tych działań była współmierna do ponoszonych kosztów. Waga tych problemów została przedstawiona w Strategii Unii Europejskiej w Zakresie Bezpieczeństwa Morskiego, przyjętej przez Unię Europejską (UE) 24 czerwca 2014 r. (UE, 2014), w której Autorzy podkreślają duże znaczenie środowiska morskiego i jego bezpieczeństwa, uznając współpracę w tym zakresie za strategiczną dla dobrobytu całej UE. Przykładem działań kooperatywnych dla zapewnienia bezpieczeństwa transportu morskiego przed działaniami piratów morskich u wybrzeży Somalii w pierwszej dekadzie XXI wieku są operacje morskie Unii Europejskiej (UE) pod kryptonimem Atalanta, operacja Paktu Północnoatlantyckiego pod kryptonimem Ocean Shield, operacje Połączonych Sił Morskich CTF 151, a także kolektywne zaangażowanie poszczególnych państw takich jak Rosja, Chińska Republika Ludowa (ChRL), Indie czy Japonia. Zaangażowanie państw w ograniczanie działań piratów jest znaczące i efektywne, ale warto również poszukać odpowiedzi na pytanie czy taka forma jest skuteczna w zwalczaniu przyczyn występowania piractwa, czy też jest to tylko kosztowny sposób jego ograniczenia, które w ocenie Autorki jest spowodowane głównie dysfunkcyjnością państw nadbrzeżnych.

Autorka w artykule syntetycznie przedstawi aktywność piratów morskich od lat 90. XX wieku do 2007 r. oraz pomiędzy latami 2008-2015, w wybranych regionach z uwzględnieniem ich znaczenia dla transportu morskiego. Ze względu na szeroki ob-
\end{abstract}


szar tematyczny ocena strategicznych działań podjętych przez społeczność międzynarodową w celu wyeliminowania piractwa zostanie zawężona do oceny reakcji na piractwo somalijskie po 2008 r. Ponadto zostanie zaprezentowany aktualny stan zagrożenia piractwem morskim na początku 2017 r. oraz potencjalne kierunki jego rozwoju w kolejnych latach w kontekście funkcjonowania państw dysfunkcyjnych, które w ocenie Autorki są kluczowe dla występowania zagrożeń asymetrycznych, jakim jest piractwo morskie.

\section{STRATEGICZNE ZNACZENIE BEZPIECZEŃSTWA MORSKIEGO W XXI WIEKU}

Żegluga morska jest postrzegana jako przykład globalnej działalności i jednocześnie istotny instrument globalizacji. Transport morski pozostaje niezmiennie najważniejszym sposobem przewożenia towarów na masową skalę w kontekście przewozów międzykontynentalnych. Stały wzrost transportowanych towarów, który w $2015 \mathrm{r}$. przekroczył rekordowy poziom 10 mld ton (Review, 2016: 6) wskazuje, że bezpieczeństwo transportu morskiego jest istotne dla rozwoju poszczególnych państw i światowej gospodarki. Bezpieczne szlaki żeglugowe to przede wszystkim gwarancja ciągłości dostaw, zwłaszcza surowców energetycznych, ale również stabilność kosztów transportu, a w konsekwencji końcowej ceny przewożonych ładunków. To również bezpieczeństwo finansowe ok. 1,5 mln marynarzy, którzy narażają swoje życie nie tylko na zagrożenia związane $\mathrm{z}$ uwarunkowaniami środowiska w którym pracuje, ale również ze względu na renesans piractwa morskiego w XXI wieku w niektórych regionach świata.

Wysoki poziom zależności sprawnego funkcjonowania państwa jest bezpośrednio związany z niezakłóconymi dostawami gazu, ropy naftowej i produktów pochodnych, które są wydobywane lub produkowane w ściśle określonych regionach świata, a w związku z tym muszą być transportowane do odbiorców. Transport morski ze względu na swobodę żeglugi jest bezpieczny i ekonomicznie korzystny pod warunkiem, że nie zagrażają mu terroryzm czy piractwo morskie. Bezpieczeństwo energetyczne w XXI wieku jest jednym z najistotniejszych elementów światowego ładu i porządku zaraz obok bezpieczeństwa międzynarodowego. W 2015 r. ropa i jej pochodne stanowiły $28 \%$ (Review, 2016: 6) wszystkich ładunków transportowanych szlakami morskimi.

Zmiana jakościowa przewożonych towarów spowodowała znaczący wzrost ich wartości, a to powoduje, że zapewnienie mu maksymalnego bezpieczeństwa przy możliwie jak najkrótszym czasie realizacji zamówienia, jest nad wyraz istotne. Oba elementy są ważnymi faktorami, obok ogólnych kosztów transportu, zarówno dla eksporterów, jak i odbiorców. Zmiana ustalonych szlaków transportu oznaczałaby dłuższą, a więc i droższą podróż dla zbiornikowców czy gazowców, co znacząco podniosłoby ogólne koszty i końcową cenę produktu. Powyższe fakty powodują, że każde zakłócenie swobodnego przepływu towarów droga morską powoduje obawy o jego efektywność ekonomiczna, a w konsekwencji reakcje społeczności międzynarodowej na występujące zakłócenia i zagrożenia. 


\section{PIRACTWO MORSKIE OD LAT 90. XX WIEKU DO ROKU 2007}

Piractwo morskie jest procederem znanym od tysięcy lat, który w niektórych częściach świata był i jest chętnie uprawiany przez lokalną ludność z powodu znacznych korzyści finansowych przy stosunkowo niewielkim nakładzie pracy. Obecność piractwa morskiego w XXI wieku nie jest zaskoczeniem, ale jego intensywność na niektórych obszarach znacząco wzrosła w ostatnich dwóch dekadach, wymuszając działania międzynarodowe w celu jego ograniczenia. Większość współczesnych działań antypirackich jest prowadzona w oparciu o definicję piractwa zawartą w art. 101 Konwencji Narodów Zjednoczonych o Prawie Morza z 10 grudnia 1982 r. Definicja ta jest raczej ogólną wykładnią podstawowych reguł obowiązujących na obszarach morskich, co powoduje, że niektóre z zawartych w niej artykułów są na dużym poziomie ogólności, a tym samym pozwalają na możliwości swobodnej interpretacji. W świetle zapisów konwencji mianem piractwa określa się działanie polegające na przemocy i grabieży na otwartym morzu, natomiast za napady rabunkowe uznaje się napady i rozbój dokonywane na statkach w ruchu lub stojących na kotwicy w obrębie wód terytorialnych (Rokiciński, 2013: 100).

Powyższe stwierdzenia pozwalają sądzić, że teoretycznie nie powinno być żadnych wątpliwości z ich rozróżnieniem, jednakże przeprowadzenie skutecznego podziału aktów na pirackie i zbrojne napady rabunkowe w ujęciu statystycznym jest trudne, zwłaszcza że motywacje sprawców w obu przypadkach posiadają charakter kryminalny. Dlatego też zdarzenia te, w przypadku statystyk Międzynarodowego Biura Morskiego (ang. International Maritime Bureau - IMB) czy Międzynarodowej Organizacji Morskiej (ang. International Maritime Organization - IMO) ujmowane są łącznie, jako bezprawne czyny skierowane przeciwko statkom, ludziom i ich mieniu oraz przeciwko bezpieczeństwu żeglugi, bez względu na to czy doszło do nich na morzu terytorialnym, czy otwartym.

Do najistotniejszych przyczyn występowania piractwa morskiego można zaliczyć geograficzne uwarunkowania obszarów, na których dochodzi do ataków, obecność intensywnie uczęszczanych szlaków komunikacji morskiej oraz być może najistotniejszy fakt, którym jest akceptacja działalności piratów w celach zarobkowych przez lokalne społeczności.

Pod koniec XX wieku, biorąc pod uwagę rozkład geograficzny ataków pirackich, na świecie można było wyszczególnić pięć obszarów dotkniętych współcześnie tym problemem. Należą do nich następujące regiony:

- Region Azji południowo-wschodniej: Morze Południowochińskie, Cieśnina Malakka;

- Region subkontynentu indyjskiego: Zatoka Bengalska, Indie, Sri Lanka, Bangladesz i Birma;

- Zachodni region kontynentu afrykańskiego: Zatoka Gwinejska, wybrzeże Nigerii;

- Wschodni region kontynentu afrykańskiego: wybrzeże Somalii z Zatoką Adeńską, Róg Afryki i wody Oceanu Indyjskiego;

- Region Ameryki Południowej: Karaiby oraz wybrzeże Peru, Brazylii i Wenezueli. W ocenie Autorki trzy z wymienionych regionów, mają kluczowe znaczenie dla międzynarodowego transportu morskiego, ze względu na usytuowanie ważnych szla- 
ków komunikacji morskiej, a są to: region Azji Południowo-Wschodniej z Cieśniną Malakka, zachodni region kontynentu afrykańskiego z Zatoką Gwinejską oraz wschodnie wybrzeże kontynentu afrykańskiego, a zwłaszcza Zatoka Adeńska, wybrzeże Somalii oraz wody Oceanu Indyjskiego. Intensywność transportu morskiego na tych akwenach powoduje, że wystąpienie jakiegokolwiek zagrożenia wymusza działania zapewniające jego bezpieczeństwo.

Cieśnina Malakka jest przykładem szlaku o dużym znaczeniu dla światowego transportu, a dodatkowo jest najważniejszą arterią komunikacyjną tego regionu. Szlak ten zajmuje drugie miejsce na świecie, pod względem ilości ropy transportowanej tym wąskim gardłem. W 2014 r. było to 15,2 mln baryłek dziennie (World, 2016: 2). Każdego roku przez cieśninę przepływa 70 tys. statków przewożących jedną piątą wszystkich światowych ładunków morskich. Szacunkowo co drugi, spośród wszystkich transkontynentalnych jednostek towarowych na świecie, raz do roku przepływa przez Cieśninę Malakka (Wardin, 2014: 112).

Na tych szlakach żeglugowych od czasów starożytnych funkcjonowało piractwo morskie. Na przestrzeni wieków było ono z większym lub mniejszym powodzeniem eliminowane czy też ograniczane przez światowe potęgi ochraniające swoje interesy. Pod koniec ubiegłego wieku był to obszar, gdzie lokalna ludność zarabiała na procederze piractwa. Niegdyś okazjonalne ataki zmieniły się w świadomy proceder uprawiany przez zorganizowane grupy, niejednokrotnie powiązane z lokalną przestępczością zorganizowaną. Dokumentacja pisemna z tego okresu jest bardzo skromna, ale dzienniki kapitanów jednostek wskazują na intensywność działań piratów. Brak raportów jest spowodowany faktem, że IMB rozpoczęło swoją działalność dopiero w 1981 r., a Centrum Raportowania Piractwa dziesięć lat później, w 1992 r. Informacje na temat częstszych ataków pirackich pojawiają się od początku lat 90 . ubiegłego wieku, a było to spowodowane dwoma ważnymi wydarzeniami, azjatyckim kryzysem finansowym z 1997 r. oraz zwiększeniem świadomości kapitanów i armatorów o możliwości zgłaszania ataku do IMB (ibid: : 134-146).

Żegluga na tych akwenach zawsze była uznawana za niebezpieczną i wymagała szczególnej czujności od załogi statku, zwłaszcza podczas nocnych przejść. Na początku XXI wieku, w 2000 r., liczba zgłoszonych ataków w regionie sięgnęła 242 (ibid.: 141), co wzbudziło duże zaniepokojenie. Podjęto działania, które miały na celu ich ograniczenie, ale analiza raportu sporządzonego na początku lipca 2004 r. przez IMB za pierwszą połowę roku, była w dalszym ciągu alarmująca. IMB wielokrotnie zgłaszało rządom Indonezji i Malezji swoje zaniepokojenie, domagając się reakcji w postaci decyzji politycznych oraz interwencji w tej sprawie poprzez zwiększenie liczby patroli morskich. Działania takie były podejmowane periodycznie, w miarę finansowych możliwości poszczególnych państw. Zaliczyć do nich można takie operacje jak: MALSINDO, MALINDO, INDOSIN czy Oczy na Niebie (ibid.: 154). Wszystkie były podjęte na początku XXI wieku i przyniosły pozytywne efekty w postaci spadku liczby ataków pirackich (na wodach cieśniny w 2005 r. IMB odnotowano tylko 12 ataków), co było niewątpliwie sukcesem.

Pomimo wyraźnej poprawy sytuacji w Cieśninie Malakka, rządy państw zdawały sobie sprawę, że nie wyeliminowano czy nawet nie ograniczono przyczyn piractwa, a w związku z tym zmniejszenie lub wycofanie się państw z regularnych działań praw- 
dopodobnie spowoduje jego renesans. Poza oczywistym faktem strat ponoszonych przez państwa nadbrzeżne, największe zaniepokojenie wyrażała Japonia, która jako państwo uzależnione od importu i eksportu drogą morska, była żywotnie zainteresowana eliminacją piractwa $w$ regionie. Intensywne działania rządu japońskiego na arenie międzynarodowej, w formie konferencji tematycznych, zakończyły się powołaniem ReCCAP ISC - Regionalnej umowy o wspótpracy $w$ sprawie zwalczania piractwa i zbrojnego rozboju wobec statków w Azji, Centrum Udostępniania Informacji (ang. Regional Cooperation Agreement on Combating Piracy and Armed Robbery against Ships in Asia, Information Sharing Centre - ReCCAP ISC). Umowa została formalnie podpisana pod koniec 2001 r., a weszła w życie dopiero we wrześniu 2006 r.

Oceniając sytuację w regionie, należy podkreślić historyczne uwarunkowanie jego występowania oraz trudności w stałej i efektywnej współpracy państw regionu w jego zwalczaniu. Aktywność rządów w tym względzie jest niewystarczająca, gdyż państwa te należą do grupy najbiedniejszych, co przekłada się na skromne możliwości finansowe przeznaczane na walkę z tym procederem. Ponadto lokalna ludność czerpie z niego znaczne korzyści, a to oznacza, że dopóki nie zmienią się warunki ekonomiczne ludności na lądzie, piractwo będzie popularną i efektywną formą zarobkowania.

Drugim regionem występowania piractwa morskiego jest Zatoka Gwinejskiej w Afryce Zachodniej, która od początku XXI wieku jest wiodącym obszarem wydobycia ropy naftowej i największym producentem produktów pochodnych na kontynencie. Do najważniejszych pod tym względem państw należą: Nigeria, Angola i Gwinea Równikowa, a od 2010 r. również Ghana (Barios, 2013: 2). Ze względu na znaczący udział wydobycia ropy z tego regionu dla państw europejskich i państw regionu (zarabiają na jej eksporcie), bezpieczeństwo wydobycia i transportu tych surowców jest kluczowe.

Piractwo na wodach Afryki Zachodniej występowało, z różną intensywnością, od czasów odkrycia tego obszaru przez portugalskiego podróżnika Vasco da Gamę. Okresem nasilenia się działania piratów, był okres niewolnictwa i handlu ludźmi, który trwał w Afryce Zachodniej od XV wieku. W odniesieniu do współczesnych przyczyn piractwa, należy brać pod uwagę głównie te czynniki, które charakteryzują cały kontynent afrykański, czyli brak stabilności politycznej i gospodarczej po zakończeniu epoki kolonialnej. Podkreślić należy, że piractwo w tym regionie pod koniec XX wieku nie stanowiło zasadniczego problemu, podobnie zresztą było na początku XXI wieku. Do ataków dochodziło głównie na wodach Nigerii, a ich intensywność zwykle nie przekraczała średnio 20 zgłoszonych ataków rocznie. Wyjątek stanowił 2003 r., w którym było 39 ataków oraz rok 2004, gdy odnotowano 29 ataków. Dopiero w 2007 r. liczba wzrosła do 42. Piractwo ma tu inny charakter niż działania w Cieśninie Malakka. Gangi piratów są zainteresowane kradzieżą produktów rafinacji ropy naftowej, głównie benzyny. Większość ataków na wodach Nigerii jest przeprowadzana na wolno idące lub zakotwiczone jednostki i stałe instalacje wydobycia ropy naftowej w pobliżu linii brzegowej lub na śródlądowych drogach wodnych. Najbardziej lukratywne są ataki na jednostki, które wydobywają, wstępnie oczyszczają i przechowują ropę ze złóż podmorskich, która potem zostaje sprzedana na czarnym rynku. Rzadziej kradnie się gotówkę, a w kilku przypadkach łupem był okup za pracowników platformy, który może osiągnąć nawet kilka milionów dolarów. Piraci z Zatoki Gwinejskiej nie uprowadza- 
ją jednostek, gdyż wymaga to lepszego przygotowania oraz współpracy z szerszym gronem osób zaangażowanych $\mathrm{w}$ pilnowanie jednostki czy negocjacje $\mathrm{z}$ armatorem w sprawie okupu.

W odpowiedzi na rosnące zagrożenie piractwa w Zatoce Gwinejskiej państwa podjęły dwustronna, regionalną i międzynarodową współpracę, w ramach której można wymienić Kod Zatoki Gwinejskiej (ang. Gulf of Guinea Code of Conduct-GoGCoC), ale kooperacja rozpoczęła się dopiero w XXI wieku, a jej efekty trudno ocenić pozytywnie skoro intensywność ataków stale rośnie.

Afryka to kontynent na którym znajduje się ponad $80 \%$ państw określanych jako dysfunkcyjne. Chociaż Nigeria i pozostałe państwa Zatoki Gwinejskiej nie są bezpośrednio zaliczane do ich grona, to jednak ich sytuacje wewnętrzne nie sprzyjają skutecznemu zwalczaniu piractwa, co uwidoczniło się w stale rosnącym trendzie od lat 90. do 2007 r. z niedużym spadkiem np. w 2006 r. (Wardin, 2014: 179). Analizując sytuacje geopolityczną można wysunąc konkluzję, że brak stabilności politycznej i gospodarczej państw Afryki Zachodniej jest prawdopodobnie najpoważniejszą przeszkodą w budowaniu skutecznych porozumień dotyczących zwalczania piractwa. Korupcja, niewydolność służb mundurowych i aparatu sądownictwa, brak świadomości znaczenia bezpieczeństwa transportu morskiego poszczególnych państw, jest kluczowy dla braku zadawalających efektów w tym względzie. Rabunkowa aktywność firm wydobywczych w regionie i złe warunki ekonomiczne lokalnej ludności powodują, że chętnie angażuje się ona w nielegalny proceder piractwa.

Podsumowując dotychczasowe rozważania należy stwierdzić, że w obu przedstawionych regionach uwarunkowania historyczne mają znaczenie, ale zdecydowanie silniejsze są one w Azji Południowo-Wschodniej. Ludność wykorzystuje tam zarówno sprzyjające uwarunkowania geograficzne, liczne wyspy i zatoki, jak również intensywność przewozów na szlakach morskich. Wschodnie wybrzeże Afryki było w przeszłości miejscem intensywnego handlu niewolnikami, co sprzyjało uprawianiu piractwa, ale w XX wieku, a zwłaszcza w latach 90. nie stanowiło ono poważnego zagrożenia dla bezpieczeństwa żeglugi międzynarodowej.

Szczególnie ważnym obszarem dla transportu morskiego są wody Oceanu Indyjskiego, które łączą kontynent azjatycki z afrykańskim, Europą, a także dalej przez Cieśninę Gibraltarską z obiema Amerykami. Priorytetem tego obszaru są wody Zatoki Adeńskiej oraz wschodnie wybrzeże, wzdłuż Somalii z wodami Oceanu Indyjskiego. Ważne dla transportu morskiego szlaki komunikacji pomiędzy Wschodem a Zachodem, na wodach Zatoki Adeńskiej i z Zatoki Perskiej powodują, że region ten charakteryzuje się dużym natężeniem ruchu, a każdego roku przepływa tam ok. 70 tys. jednostek (Wardin, 2014: 204). Ocean Indyjski skupia 36 państw nadbrzeżnych, w których mieszka 39\% ludności świata, ok. 55\% odkrytych złóż ropy naftowej i 40\% gazu ziemnego jest zlokalizowana $\mathrm{w}$ regionie Oceanu Indyjskiego, ponadto około 30\% światowego handlu i połowa wszystkich przewozów kontenerowych odbywa się położonymi tam szlakami (Podgieter, 2012: 2), w tej sytuacji znaczenie bezpieczeństwa tego obszaru jest ważne dla całej społeczności międzynarodowej.

Piractwo w Afryce Wschodniej jest niemalże w 100\% spowodowane działaniami prowadzonymi przez część ludności somalijskiej, zamieszkującej wzdłuż wybrzeża Rogu Afryki, która historycznie nie parała się nigdy tym zajęciem, a współczesne ataki 
mają swoje źródło w najnowszej historii państwa, z przełomu XX i XXI wieku. Somalia, to państwo negatywnie doświadczone okresem kolonializmu, które odzyskało niepodległości w 1960 r., a w 1969 r. władzę przejął Muhammada Siad-Barre, który dokonując zamachu stanu objął urząd prezydenta. Narastające niezadowolenie z autorytarnych rządów Siad-Barre doprowadziło do jego obalenia w 1991 r., a sama Somalia pogrążyła się w krwawej wojnie domowej. Wymiernym efektem wojny był rozpad państwa na mniejsze podmioty. 18 maja 1991 r. niepodległość ogłosiła Republika Somaliland ze stolicą w Hargejsie, a w 1998 r. kolejne dwa regiony Somalii - Puntland i Jubaland ogłosiły niepodległość. Puntland jest położony w północno-wschodniej części Somalii i jest półautonomicznym regionem ze stolicą w Garoowe. Jubaland to region w południowo-zachodniej Somalii ze stolicą w Kismaju, który posiada częściową autonomię. W Puntlandzie i Jubalandzie wykształciły się struktury państwowe i administracyjne, lecz w odróżnieniu od Somalilandu nie mają one aspiracji niepodległościowych. Ten ostatni nie jest formalnie uznawany na arenie międzynarodowej, a rząd w Mogadiszu dąży do ponownego połączenia wszystkich separatystycznych regionów w jedną całość pod flagą federacji. Ze względu na skomplikowaną sytuację geopolityczną, Autorka zdecydowała się analizować efekty międzynarodowego wsparcia i pomocy bez podziału na regiony i części autonomiczne, gdyż są one w zdecydowanej przewadze kierowane do rządu Federacji Somalii i dla całej Somalii, a nie poszczególnych jej składowych. Somaliland, jako podmiot nieuznawany na arenie międzynarodowej nie jest adresatem takiej pomocy, lub też, jak w przypadku pomocy UE, jest ona udzielana przez rząd federacyjny Somalii (EUCAP, 2017). Finansowy „sukces” regionu jest raczej efektem hojnych datków diaspory somalijskiej i prywatnych darczyńców a nie pomocy międzynarodowej.

Somalia, przed okresem wojny domowej, miała $3025 \mathrm{~km}$ linii brzegowej, a incydentalne ataki do 1991 r. nie budziły niepokoju. Nieliczne dane z tego okresu wskazują na sporadyczne ataki motywowane politycznie. Piractwo we współczesnym ujęciu pojawiło się u wybrzeży Somalii po rozpadzie państwa w 1991 r. i znaczącym zubożeniu ludności wyniszczonej wojną i klęskami naturalnymi. Grupy pirackie, które określały się mianem ,piractwa ochrony zasobów ożywionych Somalii” traktowały swoje działania jako formę poboru opłat, za połowy na wodach Somalii przez trawlery z Azji, Europy i innych państw Afryki. Chociaż liczba ataków pozostawała do 2005 r. stosunkowo niska (35 zgłoszonych), to uwagę przykuwały metody działania stosowane przez piratów, powszechne użycie broni palnej oraz nowoczesnych środków łączności. Wraz z typowym rabunkiem, którego dopuszczali się piraci, niepokojący był fakt porwań załóg napadanych jednostek oraz żądania za nich okupu.

W 2006 r. liczba ataków zmalała, ale nie było to zasługą działań międzynarodowych czy poprawy sytuacji na lądzie. Spadek ten - tylko 10 zgłoszonych ataków - był spowodowany działaniami fundamentalistów Unii Trybunałów Islamskich (UTI) i przejęciem przez nich władzy w części Somalii. 6 czerwca 2006 r. zaprowadzono na zajętych obszarach porządek i względną stabilizację. Unia zajęła się również problemem piractwa, uznając je za przestępstwo, zgodnie z wprowadzonym prawem szariatu. UTI została jednak obalona na skutek działań sił Etiopii, wspartych przez społeczność międzynarodową, gdyż w ich ocenie radykalne poglądy UTI stanowiły pożywkę dla międzynarodowego terroryzmu. Obalenie UTI znalazło swoje odzwier- 
ciedlenie w ponownym wzroście ataków pirackich w regionie Zatoki Adeńskiej i na Oceanie Indyjskim. Zagrożenie w 2007 r. rosło, a zgłoszenie do IMB 50 ataków było alarmujące.

Trwająca wojna domowa oraz klęski naturalne (głównie susza) występujące w tej części Afryki spowodowały potrzebę pomocy humanitarnej, która była dostarczana na wyczarterowanych jednostkach przez Światowy Program Żywnościowy (ang. World Food Programme - WFP). W wyniku wzrostu liczby ataków na statki transportujące pomoc w $2007 \mathrm{r}$. WFP ogłosił, że liczba chętnych jednostek do wykonywania tego zadania spadła o połowę (Axe, 2008: 1). Ponadto ataki piratów somalijskich znacznie powiększyły swój zasięg i w 2007 r. ich działania były oddalone od wybrzeża Somalii na 200 mil morskich, co oznaczało, że znaczna wschodnia część Oceanu Indyjskiego była narażona na ich działania. $Z$ tych względów społeczność międzynarodowa musiała zmierzyć się z rosnącym problemem.

\section{PIRACTWO MORSKIE W LATACH 2008-2015}

Obszary występowania piractwa pod koniec pierwszej dekady XXI wieku nie uległy zmianie, a intensywność działań piratów, poza Somalia, nie przekraczała alarmującego poziomu. Okresowa współpraca państw - głównie Malezji, Indonezji i Singapuru, w Cieśninie Malakka, w ramach wzmożonych, trójstronnych, ale periodycznych patroli, prowadziła do okresowego ograniczenia procederu. Roczne raporty IMB wskazywały niestety, że zarówno na wodach Malezji, jak i Indonezji dochodziło do stosunkowo licznych ataków. Najbardziej niepokojący wzrost zanotowano w Indonezji, gdzie na przestrzeni kolejnych lat od 2008 do 2015 liczba ta rosła, aby przez ostatnie trzy lata utrzymać się na poziome powyżej 100 zgłoszonych ataków do IMB. Niepokojący jest fakt, że ponad $90 \%$ podjętych prób kończyło się sukcesem, czyli wejściem na pokład jednostki i rabunkiem (Walje, 2014: 89). Piraci coraz częściej korzystali z doświadczeń piratów somalijskich, dochodziło do porwań jednostek oraz żądania wysokiego okupu, a takie działania w przeszłości były sporadyczne. Należy więc przypuszczać, że prowadzone operacje przez państwa nadbrzeżne nie przynoszą spodziewanych rezultatów, a brak stosowania przez armatorów tzw. dobrych praktyk związanych z zabezpieczeniem jednostki i załogi przed atakiem, jest w tym obszarze stosowany znacznie rzadziej niż w regionie Rogu Afryki.

Dobre praktyki (ang. Best Management Practices - BMP) zostały wypracowane przez społeczność marynarzy głównie w związku z działaniami piratów somalijskich. Polegają one na dodatkowych działaniach w celu uniknięcia ataku. Jednym z najbardziej rekomendowanych środków ochrony załogi przed atakiem piratów jest cytadela. Jest to specjalnie wzmocnione i zabezpieczone pomieszczenie, które ma na celu pełnić rolę miejsca, w którym załoga może się schować w sytuacji wystąpienia ataku (Wardin, 2012: 222-224). Wzrost statystyk wskazuje, że podjęte działania antypirackie, nie były skuteczne w zadawalającym stopniu. Wszystkie państwa regionu należą do grupy państw, w których sytuacja wewnętrzna jest skomplikowana. Chociaż nie można określić Malezji czy Indonezji mianem państw dysfunkcyjnych, to jednak panująca bieda na wybrzeżach powoduje, że mieszkańcy chętnie parają się piractwem. 
Piractwo w Zatoce Gwinejskiej na zachodnim wybrzeżu Afryki było rozpatrywane w kontekście rabunków na wodach terytorialnych, które na przestrzeni analizowanego okresu nie budziły niepokoju, zwłaszcza że był to problem głównie Nigerii - prawie 100\% wszystkich zgłoszonych ataków do IMB. Incydentalne ataki, które miały miejsce na wodach pozostałych państw, nie zagrażają międzynarodowemu transportowi morskiemu. Piractwo w tym regionie charakteryzuje się, tak jak i wcześniej, trzema odrębnymi, ale często nakładającymi się na siebie motywami działania: kradzież ropy, rabunek i porwania dla okupu. Ponadto charakteryzują się one wyjątkowym okrucieństwem w stosunku do załogi zaatakowanych jednostek. Chociaż region nie jest uważany za kluczowy dla światowego transportu morskiego, to jednak piractwo, utrzymując się na wysokim poziomie na przestrzeni analizowanego okresu (ok. 30 ataków rocznie), wskazuje na słabość podjętych działań w celu ograniczenia procederu. Istotne znaczenie w tej kwestii ma fakt, że państwa regionu zaliczane są do państw biednych, $\mathrm{z}$ bardzo ograniczonymi budżetami na zapewnienie porządku i bezpieczeństwa na obszarach morskich. Podjęte w 2013 r. przez państwa regionu działania w formie tzw. Kodu Zatoki Gwinejskiej, mają być regionalną platformą do zwalczania przestępczości i piractwa na morzu. Niestety, o ile świadomość potrzeby zwalczania piractwa na poziomie całego regionu jest zauważalna, o tyle w poszczególnych państwach nie jest ona priorytetem, a w związku z tym brakuje funduszy na walkę z piractwem. Brak właściwej reakcji może być odebrany przez samych piratów jako słabość społeczności międzynarodowej i sygnał dla eskalacji tego procederu, wówczas koszty jego ograniczenia będą znacząco wyższe.

W obu omówionych regionach, piractwo w latach 2008-2015 należy uznać za stale obecne zagrożenie ze zmienną intensywnością działań, ale wykazującą tendencje wzrostowe. To pozwala przypuszczać, że brak stanowczej i skutecznej odpowiedzi w celu jego ograniczenia, może skutkować w przyszłości stałym wzrostem aktywności współczesnych piratów.

Najbardziej niepokojące okazały się być działania piratów somalijskich, których intensywność rosła już do 2007 r., lecz to 2008 r. okazał się być prawdziwym przełomem w kontekście liczby ataków, która wzrosła z 50 do 111. W związku z tym kolejne lata zostały zdominowane przez piractwo w Rogu Afryki i w części Oceanu Indyjskiego oraz przez działania podjęte w celu jego ograniczenia.

Nie bez znaczenia była pogarszająca się sytuacja wewnętrzna w samej Somalii oraz konieczność niesienia pomocy humanitarnej w tym regionie Afryki. W 2008 r. ponad 3,2 mln ludności było zależne od pomocy żywnościowej WFP. Z powodu ataków piratów na statki WFP, szybko pogarszającej się sytuacji wewnątrz państwa, wspólnota międzynarodowa zgodziła się na zapewnienie wojskowej eskorty dla jednostek z pomocą WFP, która rozpoczęła się już pod koniec 2007 r. W czerwcu 2008 r. WFP poprosiła o dodatkowe konwoje, ale sytuacja pogarszała się i już nie tylko jednostki WFP były atakowane, lecz na atak narażony był każdy statek na Oceanie Indyjskim czy w Zatoce Adeńskiej.

Najnowsza historia piractwa somalijskiego od 2008 r. pokazuje, że w centrum zainteresowania znalazły się duże i nowoczesne statki przewożące nie tylko żywność dla WFP, ale transportujące ważne towary dla państw rozwiniętych. Punktem zwrotnym było uprowadzenie we wrześniu 2008 r. ukraińskiej jednostki Faina, która na swoim 
pokładzie przewoziła 33 rosyjskie czołgi typu T-72, amunicję, ręczne wyrzutnie rakiet oraz inny sprzęt wojskowy, a także porwanie saudyjskiego superzbiornikowca Sirus Star, które miało miejsce w listopadzie tegoż roku. Sirius Star przewoził w swoich zbiornikach 2 mln baryłek ropy o wartości około $100 \mathrm{mln}$ USD, a wartość samej jednostki szacowano na $200 \mathrm{mln}$ USD. Uprowadzenie obu statków oraz żądania wysokich okupów, 25 mln USD za zbiornikowiec i $35 \mathrm{mln}$ USD za transportowiec, wywołały reakcję państw na piractwo morskie. Intensyfikacja ataków w 2008 r., a zwłaszcza wydarzenia z końca roku, spowodowały, że państwa w obronie swoich interesów ekonomicznych zostały zmuszone do podjęcia konkretnych działań.

\section{DZIALANIA PODJĘTE W CELU OGRANICZENIA PIRACTWA SOMALIJSKIEGO PO 2008 ROKU I ICH KOSZTY ORAZ STAN ZAGROŻENIA PIRACTWEM PO 2016 ROKU}

Działania państw skupiły się na ograniczeniu ataków piratów somalijskich i zapewnieniu bezpieczeństwa transportu morskiego na wodach Oceanu Indyjskiego i Zatoki Adeńskiej. W tym celu Rada Bezpieczeństwa ONZ od początku 2008 r. zwracała uwagę w kolejnych rezolucjach na problem piractwa (rezolucje RB ONZ 1814, 1816, 1838, 1844, 1846, 1851) i wyrażała zadowolenie z podjętych działań, jak również upoważniała państwa do reakcji w imieniu rządu somalijskiego. Najważniejsze były inicjatywy rządów takich państw jak: Kanada, Dania, Francja, Indie, Holandia, Rosja, Hiszpania, Wielka Brytania, Stany Zjednoczone, a w szczególności planowana przez UE operacja UE NAVFOR - ATALANTA.

Od końca 2008 r., ogółem w regionie zagrożonym piractwem zostały rozpoczęte trzy operacje morskie: operacja EU NAVFOR pod kryptonimem ATALANTA, operacja NATO pod kryptonimem OCEAN SHIELD oraz działania Zespołu Okrętów CTF 151, która funkcjonuje w ramach Działań Połączonych Sił Morskich, wielonarodowego partnerstwa marynarek wojennych, powołanego z inicjatywy USA. Ponadto do ochrony linii komunikacji morskiej przyłączyły się indywidualnie takie państwa jak: Federacja Rosyjska, Republika Indii, ChRL, Japonia czy Korea Południowa. Działania zostały podjęte dopiero pod koniec 2008 r., dlatego statystyki za ten rok dotyczące zgłoszonych do IMB ataków były wysokie - 111 ataków. Pomimo zintensyfikowanej reakcji, w kolejnym roku liczba wcale nie zmalała, a wręcz wzrosła, rosła jeszcze przez kolejne dwa lata w 2011 sięgając 236 zgłoszonych ataków, z czego aż 28 zakończyło się uprowadzeniem jednostki i wzięciem załogi do niewoli, a w konsekwencji żądaniem wysokich okupów (Wardin, 2012: 329).

$\mathrm{W}$ tej sytuacji do działań antypirackich włączyły się prywatne firmy wojskowe (PFW), które zaproponowały w swojej ofercie konwojowanie lub obecność zespołu bojowego na pokładzie statku w czasie przejścia przez zagrożony region. Autorka nie rozstrzyga $w$ niniejszym artykule czy tego typu usługa jest zgodna z obowiązującym prawem, zwłaszcza w kontekście posiadania broni palnej na pokładzie jednostki handlowej, niemniej jednak od 2008 r. część armatorów korzysta z tego typu usługi regularnie, gdyż obecność uzbrojonego personelu militarnego daje prawie $100 \%$ gwarancji ochrony przed piratami. W 2014 r. eksperci z organizacji Oceans Beyond Piracy (OBP) 
szacowali, że od 35\% do 40\% wszystkich statków pływających w tzw. obszarze wysokiego ryzyka (ang. High Risk Area - HRA), wyznaczonym przez IMO w Rogu Afryki, korzysta z takiej usługi. Skuteczność wymienionych inicjatyw międzynarodowych jest dyskusyjna, a głównym zarzutem jest stwierdzenie, że liczba zaangażowanych okrętów, w stosunku do obszaru, jaki patrolują i ochraniają, jest niewystarczająca, a koszty ich obecności są niewspółmiernie wysokie do przydzielonych zadań.

Wykorzystując metodologię wypracowana przez OBP dla szacowania strat spowodowanych piractwem i kosztów poniesionych na jego ograniczenie, należy przyjąć, że poniesione przez państwa, w okresie od 2009 do 2015 r., koszty na jego ograniczenia w Rogu Afryki wyniosły ok. 24,5 mld USD (Walje, 2014: 15). Taką kwotę przyjmujemy zakładając, że straty poniesione w 2009 r. były takie same jak w 2010 (w 2010 pierwszy raz oszacowano wszystkie wydatki i koszty związane z piractwem), czyli ok. 7 mld USD, przy czym w kolejnych latach obciążenia finansowe były już malejące. Nie można jednak pominąć faktu, że w raporcie z 2010 r. szacowano, że koszty te mogły wynieść od 7 aż do 12 mld USD (Bowden, 2010: 25). W tej sytuacji uśredniając kwotę do 9,5 mld w latach 2009 i 2010 oraz dodając kolejne lata, w ciagu 6 lat wydano ok. 30 mld USD tylko na ograniczenie piractwa somalijskiego. Niepokojącym zjawiskiem jest fakt, że koszty zwalczania piractwa wzrosły z 1,3 mld w 2015 r. do 1,7 mld w 2016 r. (OBP 2016).

Całkowite koszty poniesione do 2016 r. na zabezpieczenie szlaków żeglugowych w Zatoce Adeńskiej i na Oceanie Indyjskim są wyjątkowo wysokie, zwłaszcza jeżeli weźmiemy pod uwagę fakt, że zostały one wydane tylko i wyłącznie na ograniczenie działań piratów i ochronę interesów ekonomicznych państw rozwiniętych, ale z kwoty tej nie wydano ani jednego dolara na poprawę sytuacji ekonomicznej ludności Somalii. Tym samym źródło piractwa, którym jest głównie bardzo zła sytuacja Somalijczyków nie zmieniła się, nie mówiąc o efektywnej poprawie sytuacji wewnętrznej państwa. Dlatego prawdopodobnie w kolejnych latach koszty te mogą ponownie zacząć rosnaćc.

\section{DZIALANIA SPOLECZNOŚCI MIĘDZYNARODOWEJ PO 2008 ROKU W CELU POPRAWY SYTUACJI FINANSOWEJ LUDNOŚCI SOMALIJSKIEJ}

Efekty podjętych przez państwa inicjatyw dla ograniczenia działań piratów somalijskich w Rogu Afryki należy ogólnie ocenić pozytywnie. Prowadzone w regionie operacje morskie oraz ochrona jednostek zapewniana przez PFW, prawie całkowicie wyeliminowały skuteczne ataki. Praktycznie liczba ta malała od 2012 r., a raport OBP z 2014 r. informował, że doszło tylko do dwóch udanych ataków, w których porwano jednostki rybackie. W 2014 r. pierwszy raz piratom nie udało się uprowadzić żadnej jednostki handlowej. $Z$ pewnością efekty tych działań można rozpatrywać w kategorii chwilowego sukcesu, ale czy będzie on trwały, jeżeli państwa zdecydują się na wycofanie swoich okrętów z regionu? Jaka będzie reakcja piratów somalijskich, jeżeli armatorzy uznają, że koszty ponoszone na ochronę jednostek, są zbyt wysokie i zrezygnują z usług PFW? Być może powyższe pytania są bezzasadne, o ile uznamy, że podjęte działania nie będą rozpatrywane w kategorii doraźnych, ale stałych, choć 
kosztownych działań zapewniających bezpieczeństwo transportu morskiego. W takiej sytuacji, będą one utrzymywać się na przedstawionym poziomie finansowym lub będą stopniowo, ale systematycznie, rosnąć, na co wskazuje wzrost w $2016 \mathrm{r}$.

Wszystkie wymienione do tej pory działania, mają pierwotnie na celu tylko i wyłącznie ograniczenie ataków, ale nie wpływają na poprawę sytuacji na lądzie, która jest źródłem piractwa, można więc nazwać je połowicznymi, gdyż walka skupia się na jego eliminacji, bez skutecznego zaangażowania w poprawę warunków politycznych, ekonomicznych i społecznych w samej Somalii, która jest źródłem problemu. W regionie i samej Somalii zainicjowano kilka operacji cywilnych i wojskowych przez EU - EUTUM Somalia, EUCAP Somalia - do lutego 2017 EUCAP Nestor, Regionalny Program Bezpieczeństwa Morskiego MASE, Morska świadomość i zagrożenie, przez Unię Afrykańską AMISOM, oraz liczne programy pomocowe przy współpracy ONZ i organizacji regionalnych (Wardin, 2014: 223-230). Wszystkie skupiają się na odbudowie zdolności państwa do zapewnienia bezpieczeństwa na lądzie i na obszarach morskich, ale nie zapewniają lepszych perspektyw życia dla przeciętnych Somalijczyków, którzy są odpowiedzialni za piractwo. W raporcie OBP z 2016 r. podkreślono, że nawet działania podjęte dla odbudowy zdolności państwa do zapewnienia bezpieczeństwa, są w stosunku do kosztów ponoszonych na zwalczanie piractwa niewspółmiernie małe, aby mogły przynieść w krótkim czasie poprawę sytuacji na lądzie.

W pierwszym okresie aktywności piratów takie podejście było wystarczające, ale społeczność międzynarodowa, mając świadomość wysokich kosztów tych działań, zdecydowała się na rozpoczęcie programu pomocowego dla Somalii, którego celem jest odbudowa zdolności rządu somalijskiego do wieloaspektowej rekonstrukcji państwa.

Compact for Somalia jest wynikiem procesu włączenia się UE do określania priorytetów rządu Somalii w okresie trzech lat (2014-2016). Program został zainicjowany w grudniu 2012 r. przez Federalny Rząd Somalii (ang. Federal Government of Somalia - FGS) oraz społeczność międzynarodową. Priorytety i zasady współpracy zostały opracowane na podstawie konsultacji społecznych na poziomie krajowym, jak i z partnerami międzynarodowymi. Cele, które następnie zostały sformułowane i ujęte w pięciu sektorach odnosiły się do:

- odbudowy pokoju i państwowości Somalii;

- odbudowy służb bezpieczeństwa, zapewnienie bezpieczeństwa;

- budowy systemu sądownictwa;

- budowy ekonomicznych podstaw państwa;

- budowy systemu dystrybucji dochodów i usług z pełnym poszanowaniem praw człowieka (Compact for Somalia, 2014: 3-4).

Uwzględnienie współpracy w obszarze dwóch ostatnich punków jest kluczowe dla poprawy sytuacji ludności somalijskiej. Wstępne założenia zakładały, że realizacja przyjętych celów na przestrzeni tylko pierwszego etapu trzech lat będzie szacunkowo kosztował rząd somalijski ok. 3,8 mld $€$. Najważniejszym darczyńcą jest rząd Wielkiej Brytanii, który zobowiązał się do przekazania w ciągu trzech lat kwoty $600 \mathrm{mln} €$. Ponadto pomoc finansową obiecały rządy Danii, Niemiec oraz Szwecji, co w sumie stanowiło w początkowej fazie budżet w wysokości 1,8 mld $€$ (Wardin, 2014: 267). 
Unia Europejska, jako kluczowy partner w przekazywaniu pomocy dla Somalii, wyraża się bardzo pozytywnie o zainicjowanym procesie. Niestety sami Somalijczycy są odrębnego zdania. W północnej Somalii urzędnicy państwowi we wrześniu 2015 r. ostrzegali w raportach, o możliwości powrotu Somalijczyków do piractwa, chyba że państwa biorące udział w programie zintensyfikują swoje działania na rzecz bezpieczeństwa socjalnego, tworzenia miejsc pracy oraz zapewnienia bezpieczeństwa na lądzie. Niezwykle istotną sprawą, w ocenie Somalijczyków, jest faktyczne ograniczenie nielegalnych połowów trawlerów innych państw w Wyłącznej Strefie Ekonomicznej Somalii (Harding, 2015: 1), które w dalszym ciagu nie wnoszą żadnych opłat.

Pomoc oferowana przez UE i inne państwa jest bardzo ważna z punktu widzenia darczyńców, ale z perspektywy młodych Somalijczyków, którzy w przeważającej większości są bez wykształcenia lub analfabetami, jest ona oferowana zbyt wolno i nie przynosi wymiernych rezultatów. Piractwo jest niebezpieczną formą zarobkowania, ale pomimo ryzyka „stopa zwrotu” jest bardzo wysoka. Brak realnych perspektyw zmiany życia młodych ludzi może spowodować, że piractwo ponownie stanie się lukratywnym biznesem. Zmiany zachodzące w Somalii nie następują wystarczająco szybko, aby zapewnić jej mieszkańcom poprawę życia. Wymiernym przykładem braku efektów jest fakt, że Somalia w rankingu państw dysfunkcyjnych od 2005 r. zajmuje praktycznie cały czas pierwsze miejsce, co wskazuje, że sytuacja w kraju nie poprawia się, wskaźniki dotyczące poziomu życia utrzymują się na krytycznie niskim poziomie, a demokratyzacja następuje zbyt wolno (Fragile States Index, 2016: 11-14).

Po dekadach konfliktu wewnętrznego, Somalia nadal jest zmuszona toczyć walkę o poprawę warunków wewnętrznych i utworzenie państwa narodowego, które zapewni swoim obywatelom warunki do normalnego życia. Nie bez znaczenia w tej sytuacji jest biurokratyczne podejście UE do dystrybucji zgromadzonych środków finansowych. Rząd Somalii powinien aplikować, wraz z wstępnym projektem, o przyznanie mu środków na planowaną inwestycję, natomiast proces ten jest dla niedoświadczonych urzędników administracji somalijskiej skomplikowany, co przyczynia się do popełniania licznych błędów w aplikacjach, a tym samym wydłuża proces pozyskiwania środków lub wręcz uniemożliwia go (Gabeira, 2015). Przykładem może być próba pozyskania środków przez Somalię dla realizacji projektu Safe City, który został opracowany przez polską firmę KenBIT zajmującą się produkcją i wdrażaniem najnowszych rozwiązań w zakresie projektowania sieci IT, integracją systemów łączności analogowej i cyfrowej, monitoringiem widma radioelektronicznego, mobilnymi węzłami łączności oraz systemami kierowania polem walki (KenBIT, 2017), oraz przez dra hab. Józefa Zawadzkiego. Pomimo podpisania wstępnych listów intencyjnych w 2014 r., podczas wizyty polskiej delegacji w Mogadiszu, strona Somalijska niestety nie była w stanie przebrnąć przez biurokrację i uruchomić środków na realizację projektu, który miałby zapewnić poprawę poziomu bezpieczeństwa w stolicy Somalii (Zawadzki, 2015). Jeżeli UE i pozostali darczyńcy nie ułatwią ścieżki dostępu do obiecanych środków, Somalia nie będzie w stanie skorzystać z zaoferowanej pomocy. Bez tej pomocy rząd somalijski nie ma szansy na poprawę sytuacji wewnątrz kraju. Brak bezpieczeństwa i względnej stabilności państwa skutecznie odstrasza zewnętrznych inwestorów, którzy nie chcą ryzykować utraty potencjalnie zainwestowanych środ- 
ków, a to z kolei uniemożliwia poprawę sytuacji ekonomicznej i socjalnej w państwie (BTI 2016: 18-23).

Podsumowując powyższe dane należy stwierdzić, że program Compact for Somalia nie spełnia swoich założeń w zadawalający sposób, a tym samym nie przyczynia się znacząco do odbudowy państwa somalijskiego, poprawy warunków życia, a co najważniejsze do trwałej eliminacji przyczyn piractwa morskiego w tym regionie.

\section{PIRACTWO MORSKIE - WNIOSKI I PROGNOZA}

Koniec zimnej wojny w latach 90 . XX wieku miał rozpocząc okres prosperity dla wielu państw, niestety ataki terrorystyczne z 11 września 2001 r. pokazały, że chociaż perspektywa klasycznego konfliktu pomiędzy państwami znacznie zmalała, to pojawiły się nowe zagrożenia niepaństwowe - zagrożenia asymetryczne. Piractwo morskie jest jednym $\mathrm{z}$ takich zagrożeń, ponieważ transport morski jest strategiczny dla gospodarek państw Zachodnich, więc jego bezpieczeństwo jest istotne. Działania piratów morskich w regionach ich występowania, zwłaszcza somalijskich, wymusiły reakcję państw, aby zabezpieczyć swoje interesy. Reakcja skoncentrowała się głównie na zwalczaniu działań piratów, niestety nie wypracowano skutecznych propozycji szeroko i długofalowo zaplanowanej pomocy dla ludności na lądzie, aby poprawić jej sytuację i wyeliminować źródło piractwa. Brak udanych ataków w Rogu Afryki w 2014 r. przez piratów nie oznacza, że nie odnotowano podejrzanej aktywności wobec jednostek handlowych. OBP w raporcie z $2014 \mathrm{r}$. informowała o 124 podejrzanych działaniach oraz o 18 nieudanych atakach piratów somalijskich. W raporcie z $2015 \mathrm{r}$. wskazano 16 prób ataków, a w 2016 r. było ich już 27 (OBP, 2016). W tej sytuacji właściwe jest założenie, że w kolejnych latach piractwo w Rogu Afryki może ponownie zagrozić bezpieczeństwu transportu morskiego. Do takich wniosku skłania fakt, że większość armatorów jednostek pływających na tych wodach (ok. 60\%) zdecydowała się na cięcia wydatków i rezygnację z PFW w celu zapewnienia bezpieczeństwa (Richardson, 2016: 1). Ograniczone działanie regularnie zmniejszanych sił morskich w regionie mogą okazać się zbyt słabe, aby ponownie skutecznie stawić czoła piractwu. Somalijscy piraci, którzy nadal posiadają możliwości techniczne, zaplecze personalne, broń i sieć powiązań do finansowania działań na morzu otwartym, mogą wkrótce powrócić do tego procederu. Jeżeli przedstawiony scenariusz stanie się faktem, to państwa chcąc zabezpieczyć swoje strategiczne interesy będą ponownie zmuszone do wysłania okrętów, aby kolejny raz ograniczyć bezprawne działania. W ocenie Autorki, bez względu na to czy będą to wody Zatoki Adeńskiej, Cieśniny Malakka czy Zatoki Gwinejskiej, główną przyczyną groźby takiego zagrożenia jest brak efektywnej pomocy dla państw dysfunkcyjnych, takich jak Somalia, a w tym konkretnym przypadku rozczarowanie Somalijczyków co do udzielanej im pomocy.

Nie można zignorować faktu, że niedostateczna reakcja na zagrożenie piractwem, może być sygnałem do działania dla piratów w pozostałych regionach. Według statystyk IMB w Cieśninie Malakka i Zatoce Gwinejskiej w 2016 r. ponownie odnotowano zwiększoną liczbę ataków. Piraci w Azji Południowo-Wschodniej coraz częściej uprowadzają statki, aby dokonać kradzieży transportowanej ropy lub jej pochodnych, choć 
rzadziej porywają członków załogi dla okupu. Proceder ten nasilił się już w 2015 r., a IMB ostrzegała w raporcie, że w 2016 r. piraci mogą stanowić poważne zagrożenie dla bezpieczeństwa transportu morskiego w tym regionie, który jest strategiczny dla wielu państw.

Ocena zagrożenia atakami w Zatoce Gwinejskiej od 2015 r. jest równie niepokojąca, ze względu na wzrost liczby ataków na morzu otwartym i wodach terytorialnych, głównie Nigerii. Słabość służb mundurowych państw regionu i ograniczona pomoc z zewnątrz powodują że działania antypirackie i ich efektywność są niezadawalające. W przypadku tego obszaru znaczący jest fakt powszechnej korupcji urzędników administracji państwowej każdego szczebla, który poważnie utrudnia walkę z piractwem.

Faktorem wpływającym na sytuację w 2016 r. były bardzo niskie ceny ropy i jej pochodnych, co powodowało, że opłacalność działań piratów znacznie spadła. Brak spodziewanych zarobków powoduje, że coraz częściej dochodzi do porywania załóg i żądania okupu, ale ponieważ są to na razie marynarze z lokalnych państw, to problem nie jest tak medialny, jak było to w przypadku porwań obywateli państw Zachodnich przez piratów somalijskich. Bez wątpienia narastająca frustracja ze strony biednych społeczeństw może być przyczyną wzrostu zagrożenia w tych regionach bezpieczeństwa transportu morskiego działaniami pirackimi.

Brak widocznego progresu w poprawie warunków wewnętrznych w samej Somalii oraz fakt, że w dalszym ciagu w 2016 r. piraci „testują" możliwość ataku na jednostki handlowe, pozwala na stwierdzenie, że piractwo morskie u wybrzeży Somalii nie zostało wyeliminowane, ale jedynie ograniczone.

Biorąc pod uwagę wzrost liczby ataków w $2016 \mathrm{r}$. w pozostałych regionach należy stwierdzić, że piractwo w roku 2017 i kolejnych latach może stanowić poważne zagrożenie dla transportu morskiego wielu państw na świecie. Historia pokazuje, że państwa angażowały się $\mathrm{w}$ walkę $\mathrm{z}$ tym procederem tylko $\mathrm{w}$ sytuacji poważnego zagrożenia swoich interesów, tak jak miało to miejsce w Somalii, ale działania te zawężono jedynie do ograniczenia piractwa, a nie do wyeliminowania jego faktycznych źródeł. Słabość programów pomocowych dla państw dysfunkcyjnych, takich jak Somalia, które są źródłem całego spektrum zagrożeń asymetrycznych, powoduje, że ludność tam mieszkająca będzie powracać do piractwa, a państwa będą nadal ponosić wysokie koszty na jego ograniczanie. Taka sytuacja nie jest korzystna dla żadnej ze stron, dlatego państwa tzw. „bogatej Północy” powinny solidarnie zdecydować się na udzielenie przemyślanej, bezzwrotnej i efektywnej pomocy, która zapewni faktyczną poprawę sytuacji wewnętrznej w państwach kruchych. Bez zaplanowania i wdrożenia skutecznej strategii wsparcia dla państw biednych, piractwo morskie w 2017 r. i w kolejnych latach pozostanie rosnącym zagrożeniem dla bezpieczeństwa transportu morskiego, z którym społeczność międzynarodowa będzie musiała się prędzej czy później zmierzyć.

\section{Bibliografia}

Abdulkadir Gabeira Farah, byty prezes Fundacji dla Somalii, kandydat na prezydenta Somalii, zginat $w$ ataku terrorystycznym przeprowadzonym przez organizacje terrorystycznq Asz- 
szabab w Mogadiszu 23.09.2015 podczas kampanii prezydenckiej, wywiad przeprowadzony 12.05.2015.

Axe D. (2008), Somalia: Piracy Threatens Aid Effort, Mombasa.

Barios C. (2016), Fighting piracy in the Gulf of Guinea, http://www.iss.europa.eu/ (12.03.2016).

BTI 2016, Somalia Country Report, https://www.bti-project.org, 19.05.2017.

EUCAP Somalia, https://www.eucap-nestor.eu/ (20.03.2017).

Fragile States Index, http://library.fundforpeace.org (20.02.2017).

Harding A. (2016), Somalia warns of return to piracy, http://www.bbc.com/news/world-africa (3.04.2016).

KenBIT, http://www.kenbit.pl/ (03.05.2017).

Oil and gas in Africa (2016), https://www.kpmg.com (12.03.2016).

Podgieter T. (2012), Maritime security in the Indian Ocean: strategic setting and features, „Institute for Security Studies", No. 236.

Review of maritime transport (2015), New York-Geneva.

Richardson P. (2016), Piracy threat rises for ships off Somalia, http://www.bloomberg.com/ (8.04.2016).

Rokiciński K. (2013), Asymetria na morzu. Wyzwania, szanse i zagrożenia, Sowa, Gdynia.

Strategia Unii Europejskiej w Zakresie Bezpieczeństwa Morskiego (2014), Rada Unii Europejskiej, $\mathrm{http}: / /$ register.consilium.europa.eu/ (20.05.2016).

The Economic Costs of Maritime Piracy (2010, 2011, 2012, 2013, 2014, 2015, 2016), http://oceansbeyondpiracy.org/ (20.09.2011).

The Somali Compact (2014), http://eeas.europa.eu/ (10.02.2014).

Walje M. R. (2015), The state of Maritime Piracy 2014, http://oceansbeyondpiracy.org/ (20.09.2015).

Wardin K. (2012), Wspótczesne piractwo morskie. Wyzwanie somalijskie oraz odpowiedź społeczności międzynarodowej, Warszawa.

Wardin K. (2014), Model reagowania na zagrożenie piractwem morskim, Warszawa.

World Oil Transit Chokepoints (2016), http://www.eia.gov (12.03.2016).

Zawadzki, J. profesor nadzwyczajny, kierownik Katedry Bezpieczeństwa Wyższej Szkoły Bankowej w Gdańsku, wywiad przeprowadzony 14.03.2015.

\section{STRESZCZENIE}

W artykule zaprezentowano i oceniono strategiczne podejście do problemu piractwa morskiego i jego implikacji w kontekście bezpieczeństwa transportu morskiego. Ukazano problem piractwa w najważniejszych regionach jego występowania, intensywność występowania tego problemu w latach 90. XX wieku oraz jego współczesny aspekt. Zaprezentowano i oceniono działania społeczności międzynarodowej w kontekście zwalczania piractwa morskiego oraz pomocy dla państw dysfunkcyjnych na przykładzie Somalii. Artykuł kończy się wnioskami i prawdopodobnym rozwojem omawianego procederu w kolejnych latach, w których Autorka prognozuje, że wdrożone, jak do tej pory działania przyczyniły się do ograniczenia liczby ataków, ale w niewielkim stopniu przyczyniły się do poprawy sytuacji ekonomicznej ludności somalijskiej. W związku z zanotowaniem rosnącej liczby ataków w latach 2015 i 2016, kolejne lata mogą przynieść dalszą falę renesansu piractwa. Jeżeli udzielana pomoc nie zostanie zinten- 
syfikowana i precyzyjniej wykorzystana, to piractwo morskie pozostanie realnym zagrożeniem dla transportu morskiego.

Slowa kluczowe: strategiczne podejście, piractwo morskie, państwa dysfunkcyjne, transport morski, bezpieczeństwo, pomoc międzynarodowa, efektywność

\title{
MARITIME PIRACY AND ITS IMPLICATIONS FOR MARITIME SECURITY IN THE SECOND DECADE OF THE $21^{\text {ST }}$ CENTURY - CASSUS OF SOMALIA
}

\begin{abstract}
In the article a strategic approach to the problem of maritime piracy and its implications in the context of maritime transport security is presented and evaluated. The article shows the problem of piracy in the most important regions of its presence, the intensity of the problem in the 90s of the $20^{\text {th }}$ century and its contemporary aspect. Activities of the international community in the context of maritime piracy and help for fragile States for example, Somalia are presented and evaluated. The article ends with conclusions and probable development of the piracy in the following years, in which the author predicts that the deployed action, so far contributed to the reduction in the number of attacks, but to a small extent contributed to the improvement of the economic situation of the Somali population. The growing number of attacks in 2015 and 2016, suggests that the years to come may bring a further wave of piracy renaissance. If the aid is not increased and used with better precision, maritime piracy will remain a real threat to maritime transport.
\end{abstract}

Keywords: strategic approach, maritime piracy, fragile states, maritime transport, security, international aid, efficiency 
